\title{
Valve ultrastructure of two species of the diatom genus Gomphonema Ehrenberg (Bacillariophyta) from Yunnan Province, China
}

\author{
Yan Liu ${ }^{1}$, John Patrick KocioleK ${ }^{2}$, Xinxin Lu ${ }^{1} \&$ Yawen FAN ${ }^{1 *}$ \\ ${ }^{1}$ College of Life Science and Technology, Harbin Normal University, Harbin, 150025, P. R. China, \\ "Corresponding author e-mail: fanyaw@163.com \\ ${ }^{2}$ Museum of Natural History and Department of Ecology and Evolutionary Biology, University of Colorado, \\ Boulder, CO 80309, U. S. A.
}

\begin{abstract}
We describe valve ultrastructure of two species of the freshwater diatom genus Gomphonema from a stream and Lugu Lake in Yunnan Province, China, and describe one of these two species as new to Science. Gomphonema emines Skuja was described over 80 years ago. This large, multistigmate species has uniseriate striae without occlusions, large pseudosepta and septa, and internal stigma openings that are round, positioned within ellipsoidal depressions on the extended central nodule. In these features it is distinguished from most of the 'typical' species of the genus. Gomphonema yunnaniana Y.Liu et Kociolek sp. nov. has biseriate striae without occlusions, a large, round external stigma opening and an internal stigma opening that is elevated and contained within a lip-like structure. In these features it is distinguished from the 'typical' species of the genus. We compare these two putatively endemic species from Yunnan with other species groups of the genus.
\end{abstract}

Key words: taxonomy, new species, valve ultrastructure, Gomphonema, endemic species, Yunnan, China

\section{INTRODUCTION}

The freshwater diatom genus Gomphonema Ehrenberg is a large genus of over 2400 described taxa (KocIOLEK et al. 2019). The genus has been reported from every continent on earth (KOCIOLEK 2016), including remote archipelagos such as Hawaii (KocIOLEK et al. 2015a). It is known from fossil deposits dating back to the Eocene (Benson et al. 2012), and from a wide range of fossil sites (e.g. Europe: PantocseK 1889; Heribaud 1908; North America: Kociolek \& Stoermer 1990; Africa: Stone et al., in review). In addition to the great diversity of the genus over time and space, there is also great morphological diversity in the genus. Even with some groups removed from the genus, notably Gomphoneis Cleve, Gomphocymbella Müller, Gomphosphenia Lange-Bertalot, Gomphosinica Kociolek et al. and Antiquonema Karthick \& KocioleK (in press), there still remains great morphological diversity in the genus. This diversity in morphology across the genus was discussed by KocioleK \& Kingston (1999), ReichardT (1999，2007, 2008, 2009), REICHARDT \& LANGe-Bertalot (1991), Kociolek et al. (2015a) and Levkov et al. (2016). This diversity can be related to the number and structure of the stigmata, degree of curvature of the internal proximal raphe ends, number of rows of areolae comprising each stria, size of the septa and pseudosepta, and size and position of the apical pore fields.

Yunnan Province, situated in the Southwestern part of China, is well-known as a biodiversity hotspot for Asia. It has a wide range of environmental and geological conditions, with high peaks, three major rivers coming off the Tibetan Plateau and running parallel before splitting off to the south, southwest and southeast. There are large lakes, many rivers, karst regions and hot springs found in the region. It is home to over $40 \%$ of all freshwater fish species in China (most of which are endemics, CHEN 2013), and includes 5,000 higher plant species, $80 \%$ of which are endemic to the Province (HuA 2013). Phycological research in the province can be traced back to the pioneering work of Skuja (1937) working on collections made in the region by the Handel-Mazzetti expedition. There was a long lag with respect to diatom work in the region, though some taxa were treated in studies of phytoplankton and periphyton, as well as diatoms recovered from paleolimnological studies, related to the documentation of declining water quality in some lakes at or near Kunming (e.g. Hu et al. 2012; CHEN et al. 2015; Liv et al. 2016), the largest city in the province. More than 15 species of diatoms have been described from Yunnan 
province (Table 1)

The purpose of the present report is to describe and document one new species of Gomphonema from Yunnan Province with light (LM) and scanning electron microscopy (SEM) and to present observations on $G$. eminens Skuja, a species endemic to the region (SKUJA 1937) and still extant. We compare the morphology of these species to others in the genus and, in particular, species similar to G. acuminatum Ehrenberg, the type species of the genus.

\section{MATERIALS AND METHODS}

Diatom samples were taken from surface sediments of a stream in Dali old town, western Yunnan Province on July 2014. At the time of collection, $\mathrm{pH}$ was determined to be 9.2, water temperature was $24.1^{\circ} \mathrm{C}$ and conductivity was 160 $\mu \mathrm{s} . \mathrm{cm}^{-1}$, respectively (KL-009III Pen-based high-precision $\mathrm{pH}$ meter, DDB-11A Portable digital conductivity meter). Samples were field-fixed with $4 \%$ formaldehyde. Both species treated in this paper occurred in same sample. Gomphonema eminens also was observed from epiphytic samples in Lugu Lake, northern Yunnan Province. Environmental factors at the site in Lugu Lake were recorded with the same instruments and determined to be: $\mathrm{pH}=8.46$, water temperature was $20.1^{\circ} \mathrm{C}$ and conductivity was $260 \mu \mathrm{s} . \mathrm{cm}^{-1}$.

Samples were boiled in nitric acid for 4 hours and washed with distilled water in the laboratory. Cleaned materials were preserved with distilled water. For LM observations, the cleaned material was air-dried on coverslips and then mounted onto microscope slides in Naphrax. Light microscope observations were made with an Olymbus BX 51 microscope, equipped with an Olymbus DP 71 camera (1000× magnification, Differential Interference Contrast, University of Colorado). For SEM observations, cleaned material was air-dried and coated with gold/palladium on copper stubs and observed with a Hitachi S-4800 field emission electron microscope (Harbin Normal University) at an operating voltage of $15 \mathrm{kv}$.

Material and slides are housed at Key Laboratory of Biodiversity of Aquatic Organisms, Harbin Normal University and Diatom lab at the University of Colorado, Boulder. Diatom images were compiled with Photoshop 7.0.

\section{RESULTS}

Gomphonema eminens Skuja, Figs (1-7, LM; 8-19, SEM)

Valves linear- to elliptical-clavate, with headpole broadly rounded and footpole rounded. Length 64.0-122.3 $\mu \mathrm{m}$, breadth $15.7-19.6 \mu \mathrm{m}$. Axial area distinct, straight, broadening slightly to the central area. Central area a unilaterally expanded fascia extended to the margin on one side, with striae slightly more coarse and 2-3 isolated stigmata on the other side. Raphe straight, lateral, with external proximal raphe ends dilated slightly and gently bent towards the stigmata. Striae parallel to weakly radiate, radiate at the footpole,
Table 1. Listing of freshwater diatoms described from Yunnan Province, China.

\begin{tabular}{|c|c|}
\hline Species & Reference \\
\hline $\begin{array}{l}\text { Aulacoseira dianchiensis Yang et } \\
\text { al. }\end{array}$ & YANG et al. (1994) \\
\hline $\begin{array}{l}\text { Melosira radiato-sinuata var. yun- } \\
\text { nanica } \text { Chen }\end{array}$ & CHEN (1980) \\
\hline $\begin{array}{l}\text { Cyclotella rhomboideo-elliptica } \\
\text { Skuja }\end{array}$ & SKUJA (1937) \\
\hline $\begin{array}{l}\text { Ceratoneis arcus var. orientalis } \\
\text { Skuja }\end{array}$ & SKUJA (1937) \\
\hline Gomphonema eminens Skuja & SKUJA (1937) \\
\hline $\begin{array}{l}\text { Gomphosinica lugunsis Y.Liu, Ko- } \\
\text { ciolek, You et Fan }\end{array}$ & $\begin{array}{l}\text { CHENG et al. } \\
(2018)\end{array}$ \\
\hline $\begin{array}{l}\text { Gomphonema tumida Y.Liu et Ko- } \\
\text { ciolek }\end{array}$ & JIANG et al. (2018) \\
\hline $\begin{array}{l}\text { Halamphora subfontinalis Q.M.You } \\
\text { et Kociolek }\end{array}$ & You et al. (2015) \\
\hline Navicula aktinoides Skuja & SKuJA (1937) \\
\hline $\begin{array}{l}\text { Navicula craticuloides Li et Met- } \\
\text { zeltin }\end{array}$ & GoNG et al. (2015) \\
\hline $\begin{array}{l}\text { Navicula cryptocephala var. austra- } \\
\text { lis Skuja }\end{array}$ & SKUJA (1937) \\
\hline Navicula gongii Metzeltin et Li & GoNG et al. (2015) \\
\hline Navicula praegnans Skuja & SKUJA (1937) \\
\hline Navicula setschwanensis Skuja & SKUJA (1937) \\
\hline $\begin{array}{l}\text { Navicula yunnanensis Li et Met- } \\
\text { zeltin }\end{array}$ & GoNG et al. (2015) \\
\hline Sellaphora yunnanensis $\mathrm{Li}$ & Li et al. (2010a) \\
\hline $\begin{array}{l}\text { Sellaphora yunnanensis Li et Met- } \\
\text { zeltin }\end{array}$ & Li et al. (2010b) \\
\hline Sellaphora sinensis Li et Metzeltin & Li et al. (2010b) \\
\hline
\end{tabular}

distinctly punctate, $6-8 / 10 \mu \mathrm{m}$ in the center, $10-11 / 10$ $\mu \mathrm{m}$ near the apex. Apical pore fields (APF's) bilobed, distinct. In girdle view there is a small spine located at the apex of the valve. In the SEM, the valve exterior has uniseriate striae and a distinct central area (Figs 8-12). The headpole bears a short but distinct spine, noticeable in valve (Fig. 9) and girdle (Fig. 13) views. At the headpole the external distal raphe end is hooked 


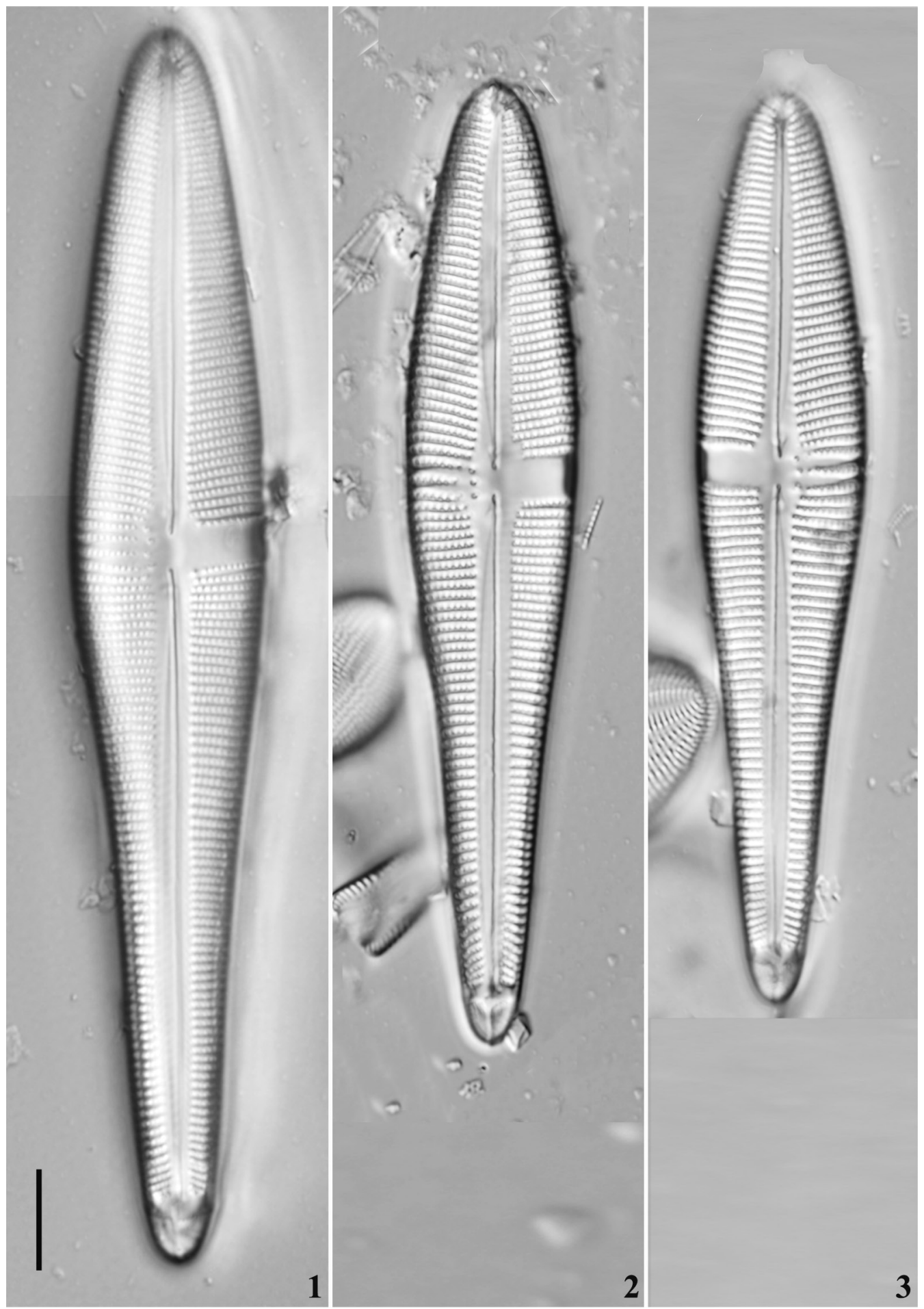

Figs 1-3. Gomphonema emines Skuja. LM. Valve views. Scale bar $10 \mu \mathrm{m}$.

onto the mantle (Fig. 9). Striae are uniseriate, without any occlusions (Figs 9-12). In the center of the valve, the proximal raphe ends are dilated slightly, and the stigma openings are round, similar in shape to the areolae, but larger than the areolae (Fig. 11). At the footpole, the porelli of the APF are nearly the same size and shape as the areolae, but packed more tightly together. The distal raphe end is deflected before it bisects the APF. Porelli extend well onto the valve face and across the valve mantle (Fig. 14). Girdle bands are numerous and of the open type (Figs 13, 14). Internally, the valve is dominated by the asymmetrical central fascia and wide axial area. Pseudosepta are present at each pole (Figs 15-19). Helictoglossae are present at the headpole, where it may be obscured by the pseudoseptum (Fig. 16), and footpole, where it is positioned well before the pseudoseptum (Fig. 18). In the central area, the proximal raphe ends are curved or deflected at 


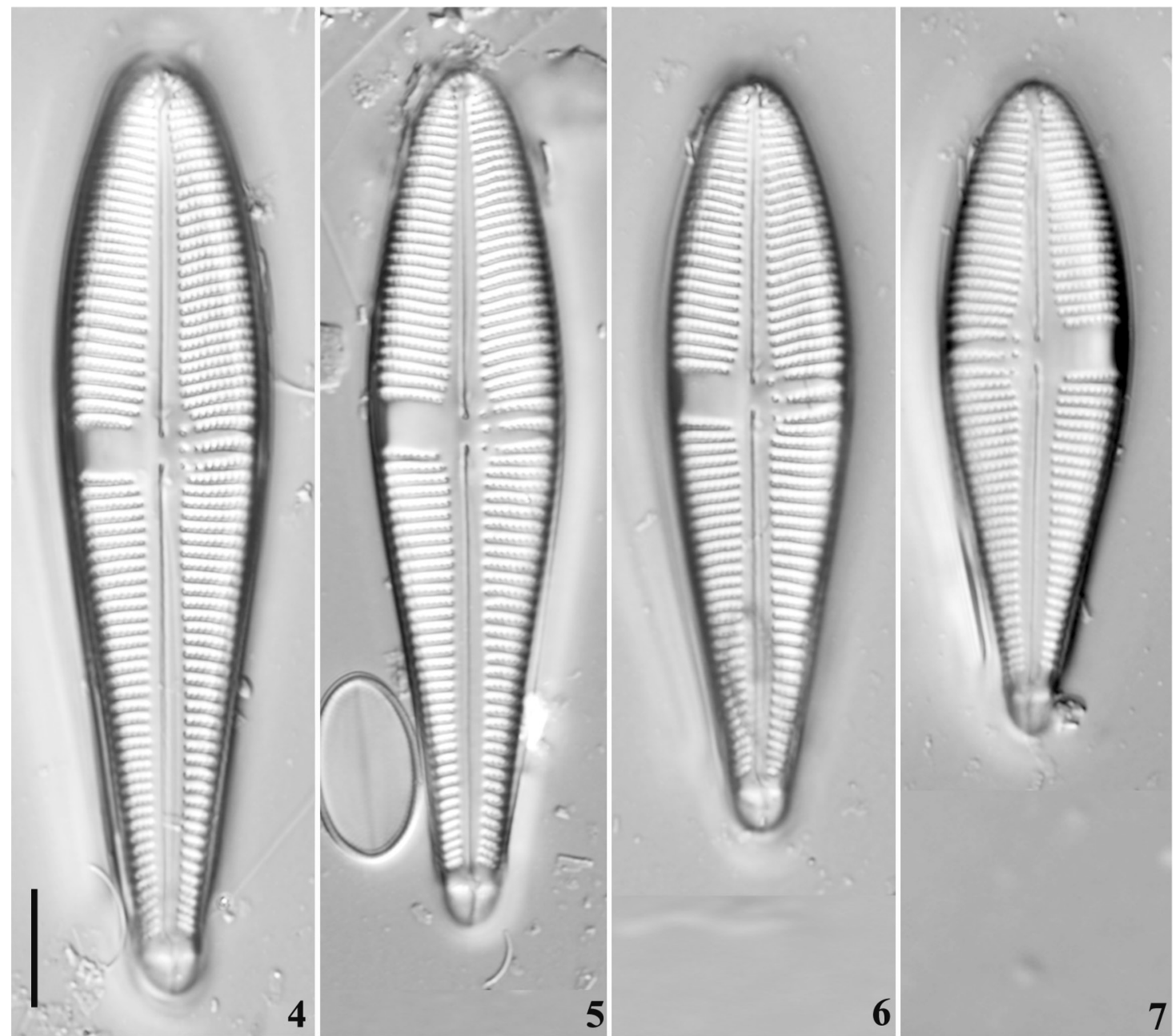

Figs 4-7. Gomphonema emines Skuja. LM. Valve views. Scale bar $10 \mu \mathrm{m}$.

almost a 90-degree angle and positioned on the elongated central nodule. Stigma openings are round holes within slightly elongated openings (Fig. 17). Within the striae, there are small tooth-like projections, one from each side, alternating with the round, unoccluded areolar openings (Figs 16-19).

Gomphonema yunnaniana, Y.Liu et Kociolek, sp. nov., Figs (20-31, LM; 32-43 SEM)

Description: Valves elliptical-clavate, with headpole rostrate and footpole subrostrate, length 18.3-31.0 $\mu \mathrm{m}$, breadth 7.3-9.0 $\mu \mathrm{m}$. Axial area narrow, more or less straight, broadening to form an irregular central area with alternating longer and shorter striae. Near the center of the valve on one side of the central area is a distinct, round stigma opening. Raphe very weakly undulate, with external proximal raphe ends dilated slightly. Striae are broad, individual areolae are not visible, and radiate, 13-16/10 $\mu \mathrm{m}$. Small septa and pseudosepta present at the poles. APF indistinct at the footpole. In the SEM, the valve exterior has striae composed on double rows of areolae. The striae terminate with a single areola bordering the axial area (Fig. 32). The stigma opening is round and large. The raphe is narrow and has dilated proximal ends (Figs 32, 36, 37). Areolae are without occlusions (Figs 34-39). At the headpole (Figs 34, 35) the raphe can be seen to curve onto the mantle. Striae extend around the headpole. At the footpole, the distal raphe end hooked onto the mantle and bisects the APF. Porelli are located mostly on the valve mantle, and appear similar to the areolae in size and shape, being more densely packed than the areolae (Figs 38, 39). Internally, the headpole and footpole have short pseudosepta (Figs 40, 41). At the footpole, the porelli appear occluded, but occlusions are lacking in the areolae (Fig. 41). The central area (Figs 42, 43) has a central nodule that projects well into the valve interior. The proximal raphe ends are hooked and positioned at the ends of the elongated central nodule. The stigma opening appears like a pair of lips, similar in structure to the helictoglossae. The round areolae are without occlusions.

Holotype: HANU! Slide no. THYN2014375 (Harbin Normal University, Harbin, China). Fig. 20 is of the holotype specimen.

Isotype: COLO! Kociolek Collection (University of Colorado, Boulder, U.S.A.). 


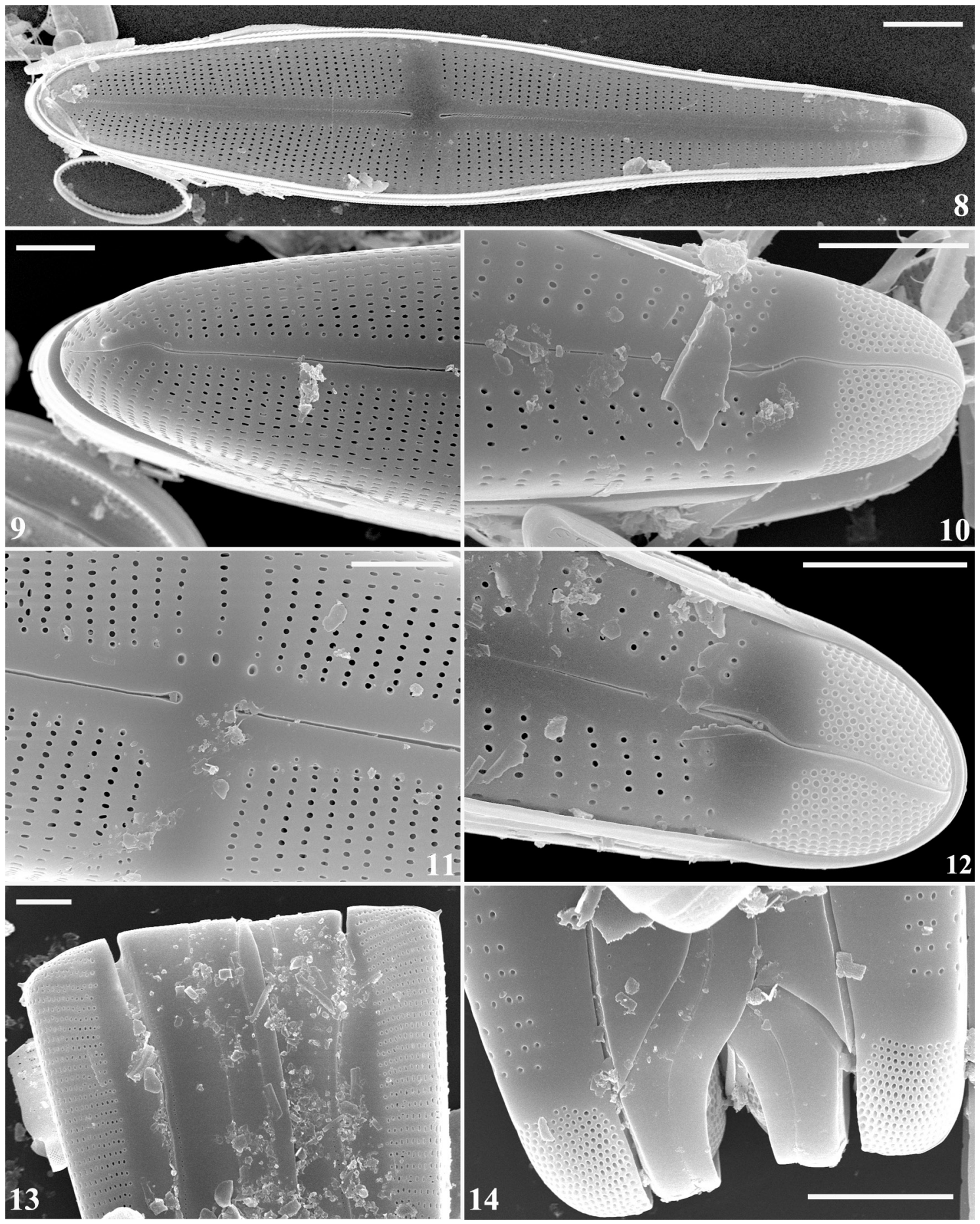

Figs 8-14. Gomphonema emines Skuja. SEM, external views: (8) entire valve view; (9) headpole, with distal raphe end and small spine evident; $(10,12)$ footpole, with large apical pore fields shown, distal raphe end bisects the pore field; (11) central area, with dilated proximal raphe ends and several stigmata evident; $(13,14)$ girdle views: $(13)$ headpole, with small spines evident, girdle bands are of the open type; (14) footpole, with apical pore fields and girdle bands are of the open type. Scale bar (9-14) $5 \mu \mathrm{m}$, (8) $10 \mathrm{~mm}$.

Material no. 11662 , slide no. 611032

Type locality: Stream, Dali old town, Dali city, Yunnan Province, China.

Surface sediment of the stream. Collected at July 2014, by Liu Y. et al.

Etymology: Named for the province in which it was discovered (Yunnan Province).

\section{Discussion}

The two species presented here differ from the 'typical' species of Gomphonema, exemplified by G. acuminatum, the type species of the genus, in several key morphological characteristics. In the G. pumilum group (REICHARDT 1997), and other classical species groups such as G. acuminatum, G. affine, G. angustatum and 


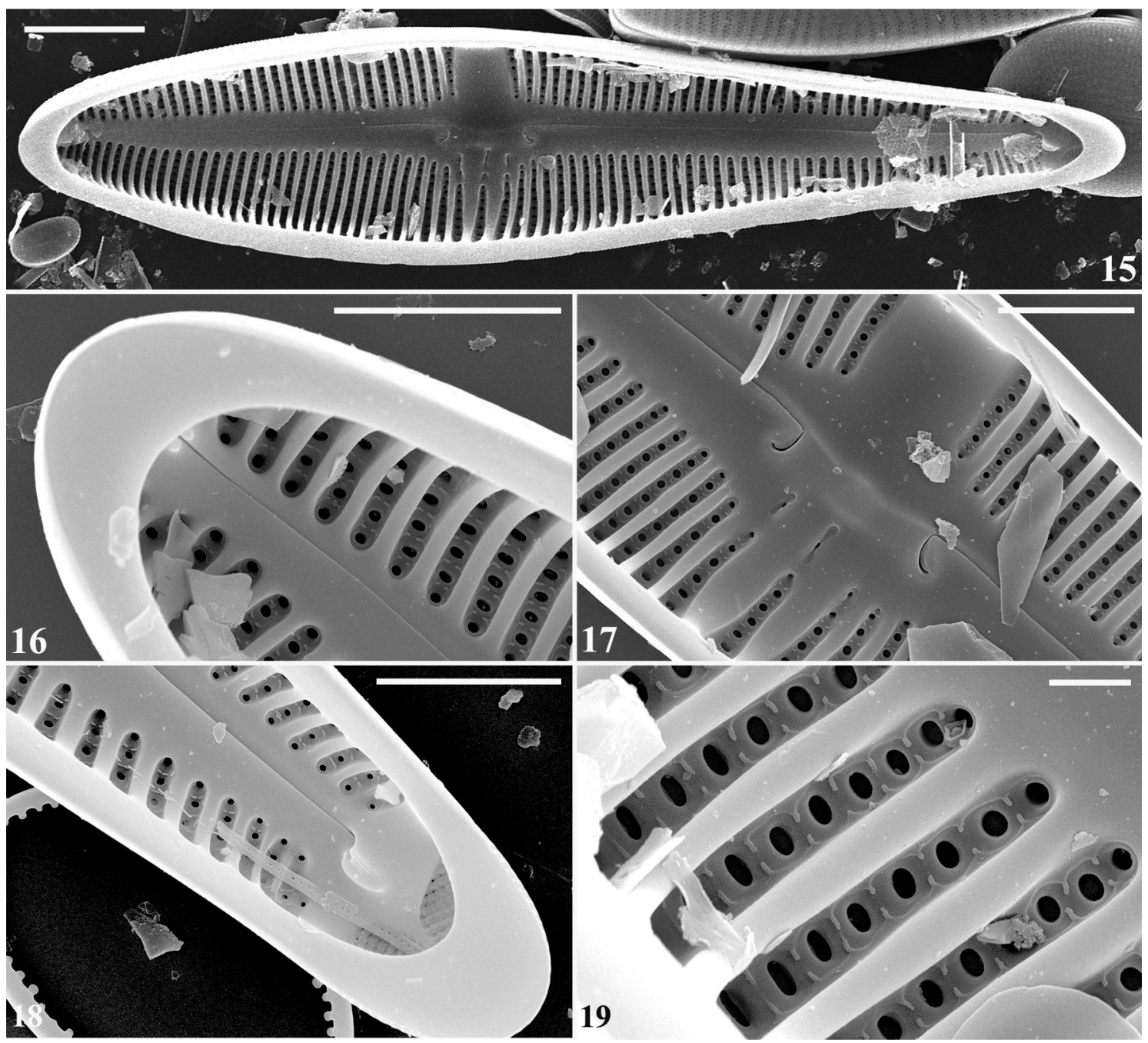

Figs 15-19. Gomphonema eminens Skuja. SEM, internal views: (15) entire valve view. Broad axial area with expanded central area dominate the interior. Pseudosepta are evident at the poles. (16) headpole, with large pseudoseptum obscures the helictoglossa; (17) central area, with unequally-expanded central area. Recurved proximal raphe ends and stigma openings are shown on the elongated central nodule. (18) footpole, with pseudoseptum and helictoglossa evident. Porelli of the pore field are obscured by the pseudoseptum. (19) high magnification view of striae, with tooth-like projections evident. Scale bar (15) $10 \mu \mathrm{m},(16-18) 5 \mu \mathrm{m},(19) 1 \mu \mathrm{m}$.

relatives (REICHARDT 1999) and many others whose valve ultrastructure is well-documented (LEVKOV et al. 2016), the areolae are occluded on the exterior by projections that yield the aperature to be a narrow, lunate to irregular opening. Septa and pseudosepta are narrow, and the single internal stigma opening is a narrow slit.

In the two species presented herein, we see variation in these characters that are structurally quite different from the 'typical' species of Gomphonema. In $G$. eminens, striae are composed of uniseriate rows of round, unoccluded areolae and in G. yunnaniana sp. nov. the striae are composed of biseriate rows of unoccluded areolae. While there are several species of Gomphonema that have biseriate striae (e.g. G. zairense, COMPERE 1995; G. intermedium HustedT 1942; see also REICHARDT 2007) nearly all of them have areolae occluded externally. In both species studied here, and especially in G. eminens, the pseudosepta are large and quite distinct. In some other large species, such as G. gomphopleuroides Amosse et Kociolek et al. (Kociolek et al. 2015b), G. firmum Skvortzow (Kulikovskiy \& KocioleK 2015) and G. grande KARTHICK et al. (2016), the septa and pseudosepta are large, and these species also bear a single spine at the headpole. Perhaps the greatest variation found in species assigned to the genus Gomphonema is in the internal structure of the stigma. Both $G$. eminens and G. yunnaniana have internal stigmata that differ from the 'typical' Gomphonema species. In many of the 'typical' species, the stigma opening is a single narrow slit (e.g. ReICHARDt 1999), while in G. eminens there are 2-3 stigmata and their internal openings are more ovoid, with the round opening of the stigma visible. In other multistigmate species, the internal openings of the stigmata are slit-like (STONE et al., in review). In G. yunnaniana the internal stigma opening is elevated, surrounded by a pair of thickened lips, similar in appearance to the helictoglossae. This stigma type 

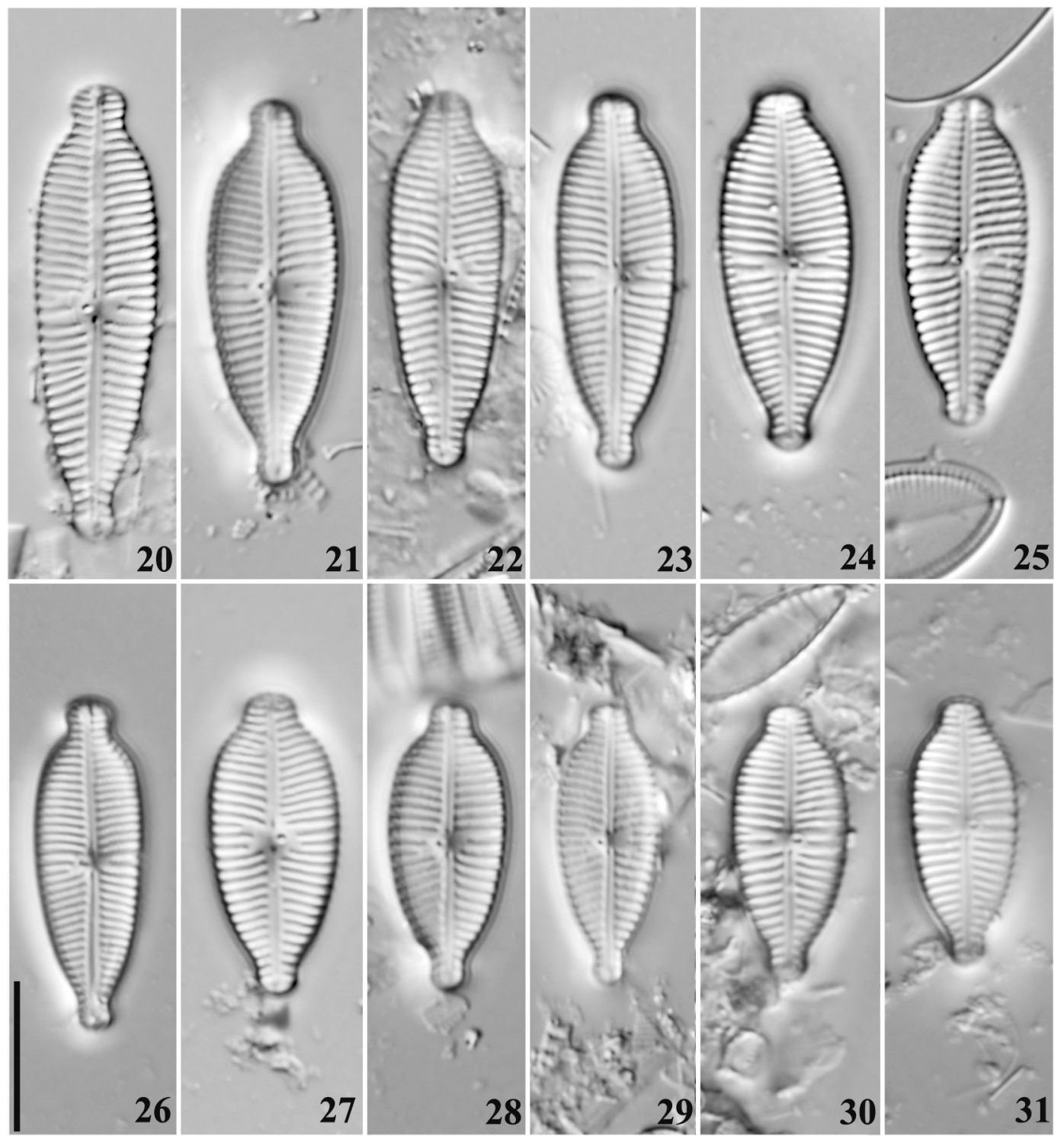

Figs 20-31. Gomphonema yunnaniana, Y. Liu et Kociolek, sp. nov. LM. Valve views. Scale bar $10 \mu \mathrm{m}$.

structure is seen also in G. grande (KARTHICK et al. 2016); it was absent from the morphological diversity seen in species considered by LEVKOV et al. (2016).

Our observations on $G$. emines differ slightly from those of SKuJA (1937), in that his specimens were longer $(114-190 \mu \mathrm{m})$ than ours, with slightly finer striae $(11-12 / 10 \mu \mathrm{m})$. Otherwise the specimens from the two sites we report here fit the description and images provided in the original work of SKUJA (1937). Gomphonema eminens resembles $G$. tropicale BRUN in SCHMIDT (1899: plate 216, figs 3, 4), with both species being large, multi-stigmate, and having a wide, unilaterally-expanded central area. Both species are known from Asia. The two differ in the shape of the valves, with $G$. tropicale having much longer, narrower valves. Our report of this species appears to be the first since its original description. It was not included, for example, in the treatment of gomphonemoid diatoms from China by SHI (2004).
G. yunnaniana bears a slight resemblance to some interpretations of $G$. parvulum (Kützing) Kützing, though $G$. yunnaniana is much wider and has a rostrate, not capitate headpole (WALlace \& PATRICK 1950; PATRICK \& ReIMER 1975). In addition, the striae of $G$. parvulum are distinctly uniseriate. Gomphonema yunnaniana more closely resembles $G$. pseudoparvulum KocioleK et al. (2016), a species described from a stream on the island of Kauai, Hawaii. The two species differ, however, in overall shape (the Chinese specimens are comparatively more elliptical in outline, though the smallest specimens of the two species are quite similar in outline), the number of rows of areolae in the striae (1-2 in G. pseudoparvulum, 2 in G. yunnaniana), presence ( $G$. pseudoparvulum) or absence ( $G$. yunnani$a n a)$ of areolar occlusions, and structure of the stigma (a flat, narrow slit in G. pseudoparvulum, an elevated lip-like border along the slit in G. yunnaniana).

The diversity in morphology of species assigned 


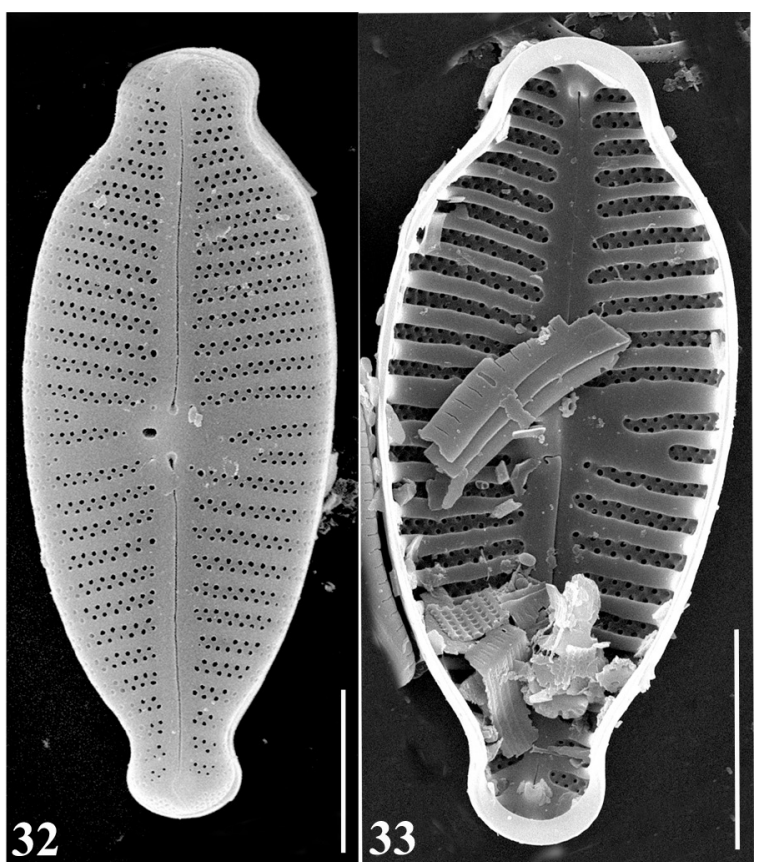

Figs 32-33. Gomphonema yunnaniana, Y. Liu et Kociolek, sp. nov. SEM, valve views: (32) external view, with biseriate striae and large round stigma opening; (33) internal view, pseudosepta and biseriate striae are shown. Scale bar $5 \mu \mathrm{m}$.

to Gomphonema is quite large, and greater than that seen in other genera. For example, the genus Navicula sensu stricto includes species only with lineolate striae (LANGe-Bertalot 2001). And in the closely allied group of cymbelloid diatoms, the genera Encyonema and Oricymba have fairly uniform stigma openings (KRAMMER 1997; JüTTNER et al. 2010). Diversity of internal stigma openings of a magnitude similar to Gomphonema is shown in the genus Cymbella, another genus, like Gomphonema, with over 2,000 named taxa (KocIOLEK et al. 2019). The diversity of features demonstrated in Gomphonema by a wide range of authors seems to suggest that genus is ripe for a major revision, as was done for Cyclotella sensu lato (LowE 1975; THERIOT et al. 1987; HAKANSSON \& KHURSEVICH 1997; Khursevich \& KocioleK 2002; HouK \& KLEE 2004; KhURSEVICH \& KocioleK 2012; KocioleK et al. 2016b; Acs et al. 2016;), Navicula sensu lato (LANGEBertalot 2001), Eunotia sensu lato (Metzeltin \& LANGE-Bertalot 2007; TAYLOR et al. 2014; Burliga et al., 2013; Wetzel et al. 2012; Wetzel \& KocioleK 2018) and Cymbella (KocIOLEK \& STOERMER 1987; Krammer 1997, 1999, 2003; MetZeltin et al. 2009; BAHLS 2015; Kapustin et al. 2017).

\section{ACKNOWLEDGMENTS}

The present study was supported by the National Natural Science Foundation of China (NSFC 31670201, 31970213, 31870187) and University Nursing Program for Youth Scholars with Creative Talents in Heilongjiang Province, China (12521156).

\section{REFERENCES}

Ács, E.; Ari, E.; Duleba, M.; Dressler, M.; GenKal, S.I.; JAKÓ, E.; Rimet, F.; EстOR, L. \& Kiss, K.T. (2016): Pantocsekiella, a new centric diatom genus based on morphological and genetic studies. - Fottea 16: $56-78$.

BAHLS L. (2015): Kurtkrammeria, a new genus of freshwater diatoms (Bacillariophyta, Cymbellaceae) separated from Encyonopsis. - Nova Hedwigia 101: 165-190.

Benson, M.E.; Kociolek, J.P.; Spaulding, S.A. \& SMith, D.M. (2012): Pre-Neogene (>23.8 MA) biochronology of non-marine diatoms, with an account of the late Eocene flora of the Florissant Formation, central Colorado, USA. - Stratigraphy 9: 131-152.

Burliga, A.L.; KocioleK, J.P.; SAlomoni, S.E. \& Figueiredo, D. (2013): A new genus and species in the diatom family Eunotioiaceae Kützing (Bacillariophyceae) from the Amazonian hydrographic region, Brazil. - Phytotaxa 79: 47-57.

Chen, J. (1980): Notes on some new species and variety of the genus Melosira (Bacillariophyta). - Acta Hydrobiologica Sinica 7: 253-256.

Chen, X.; Chen, G.; Lu, H.; Liu, X \& Zhang, H. (2015): Long-term diatom biodiversity responses to productivity in lakes of Fuxian and Dianchi. - Biodiversity Science 23: 89100.

CHEN, X.Y. (2013): Checklist of fishes of Yunnan. Zoological Research 34:281-343. doi: 10.11813/j. issn.0254-5853.2013.4.0281

Cheng, Y.; Liu, Y.; Kociolek, J.P.; You, Q. \& FAn, Y. (2018): A new species of Gomphosinica (Bacillariophyta) from Lugu Lake, Yunnan Province, SW China. Phytotaxa 348: 118-124.

Compere, P. (1995): Gomphonema zairense sp. nov. from the Tshopo waterfalls (Kisangani, Zaire). - Diatom Research 10: 31-37.

Gong, Z.; Metzeltin, D.; Li, Y. \& Edlund, M.B. (2015): Three new species of Navicula (Bacillariophyta) from lakes in Yunnan Plateau. - Phytotaxa 208: 135-146.

Hakansson, H. \& Khursevich, G. (1997): Tertiarius gen. nov, a new genus in the Bacillariophyceae, the transfer of some cyclotelloid species and a comparison to closely related genera. - Diatom Research 12: 19-33.

HÉRIBAud, J. (1908): Les Diatomées Fossiles d'Auvergne (Troisième Mémoire). - pp. v-x, 1-70, Librairie des Sciences Naturelles, Paris.

Houk V. \& KLEE R. (2004): The stelligeroid taxa of the genus Cyclotella (Kützing) Brébisson (Bacillariophyceae) and their transfer into the new genus Discostella gen. nov. - Diatom Research 19: 203-228.

Hu, Z.; LI, Y.; \& LI, S. (2012): Spatial and temporal distributions of diatom communities and their relationships with environmental factors in Lake Erhai. - Journal of Lake Sciences 24: 400-408.

HuA, Z. (2013): The floras of southern and tropical Southeastern Yunnan have been shaped by divergent geological histories. - PLoS One. 8: e64213.

HustedT, F. (1942): Süßwasser-Diatomeen des indomalayischen Archipels und der Hawaii-Inslen. Internationale Revue der gesamten Hydrobiologie und Hydrographie 42: 1-252.

JiAng, Z.; LiU, Y.; Kociolek, J.P. \& Fan, Y. (2018): One new Gomphonema (Bacillariophyta) species from Yunnan Province, China. - Phytotaxa 349: 257-264. 


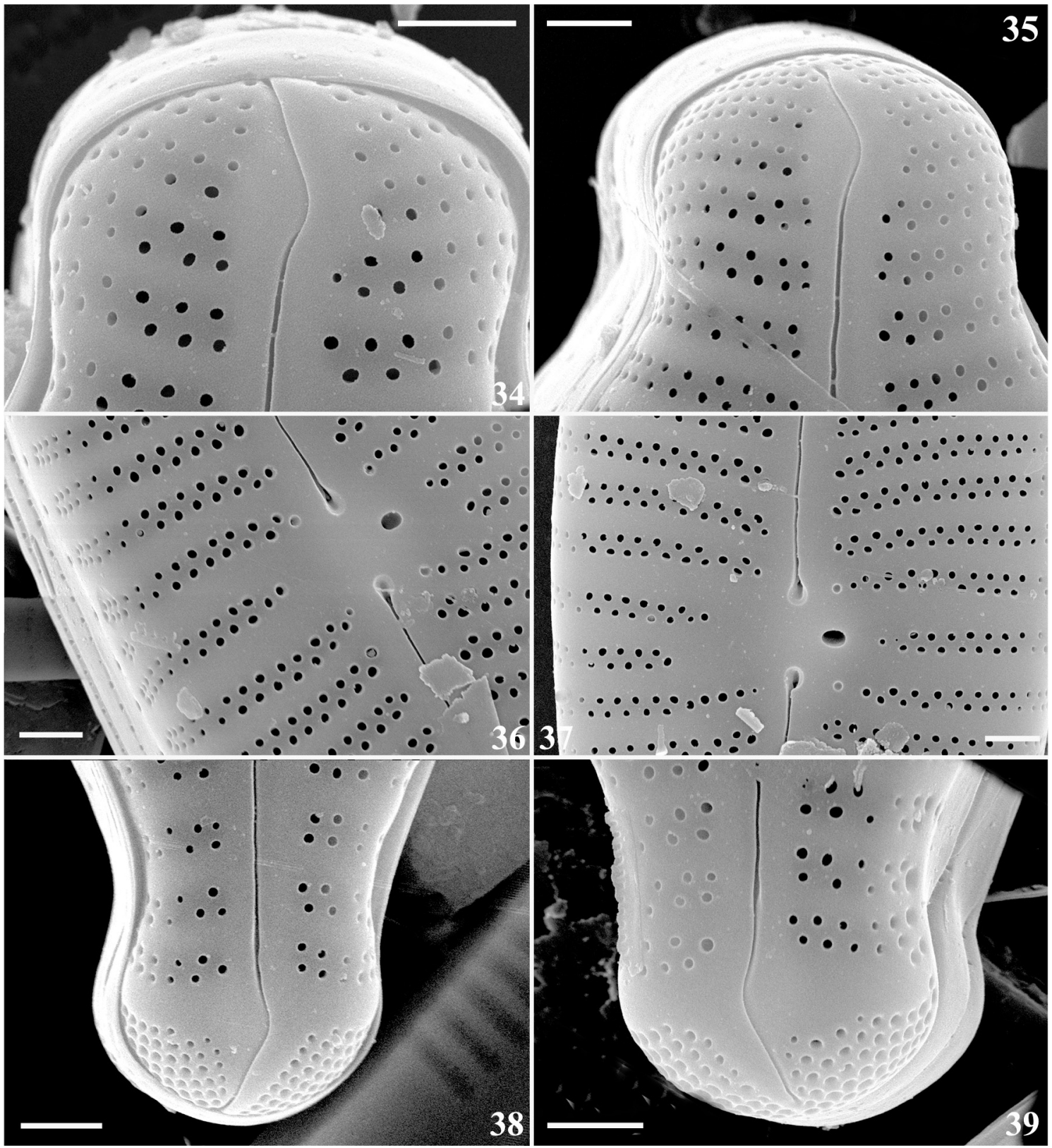

Figs 34-39. Gomphonema yunnaniana, Y. Liu et Kociolek, sp. nov. SEM, external valve views: $(34,35)$ headpole views, showing biseriate striae and distal raphe end deflected onto the mantle; $(35,37)$ central area, showing dilated proximal raphe ends, biseriate striae and large, round stigma opening; $(38,39)$ footpole, with apical pore fields positioned mostly on the mantle. Distal raphe ends are deflected and bisect the pore fields. Scale bars $1 \mu \mathrm{m}$.

JÜtTner, I.; Krammer, K.; Van De ViJver, B.; Tuji, A.; Simkhada, B.; Gurung, S. \& Cox, E.J. (2010): Oricymba (Cymbellales, Bacillariophyceae), a new cymbelloid genus and three new species from the Nepalese Himalaya. - Phycologia 49: 407-423. https://doi.org/10.2216/09-77.1

Kapustin, D.A.; KulikovskiY, M. \& Kociolek, J.P. (2017): Celebesia gen. nov., a new cymbelloid diatom genus from the ancient Lake Matano (Sulawesi Island, Indonesia). - Nova Hedwigia, Beiheft 146: 147-155.

Karthick, B.; Kociolek, J.P.; TAYlor, J.C. \& CocQuyt, C. (2016): Gomphonema grande sp. nov., a new diatom (Bacillariophyta) from the Democratic Republic of the Congo, tropical Africa. - Phytotaxa 245: 187-196.
Khursevich, G.K. \& KocioleK, J.P. (2002): New Tertiarius (Bacillariophyta: Stephanodiscaceae) species from western North America. - In: J. John (ed.), Proceedings of the 15th International Diatom Symposium. - pp. 331-350, A.R.G. Gantner Verlag, Liechtenstein.

Khursevich, G.K. \& Kociolek, J.P. (2012): A preliminary, worldwide Inventory of the extinct, freshwater fossil diatoms from the orders Thalassiosirales, Stephanodiscales, Paraliales, Aulacoseirales, melosirales, Coscindiscales, and Biddulphiales. - Nova Hedwigia, Beihefte 141: 315-364.

Kociolek, J.P. (2016): A worldwide listing and biogeography of freshwater diatom genera: A phylogenetic perspective. - Diatom Research. DOI: 

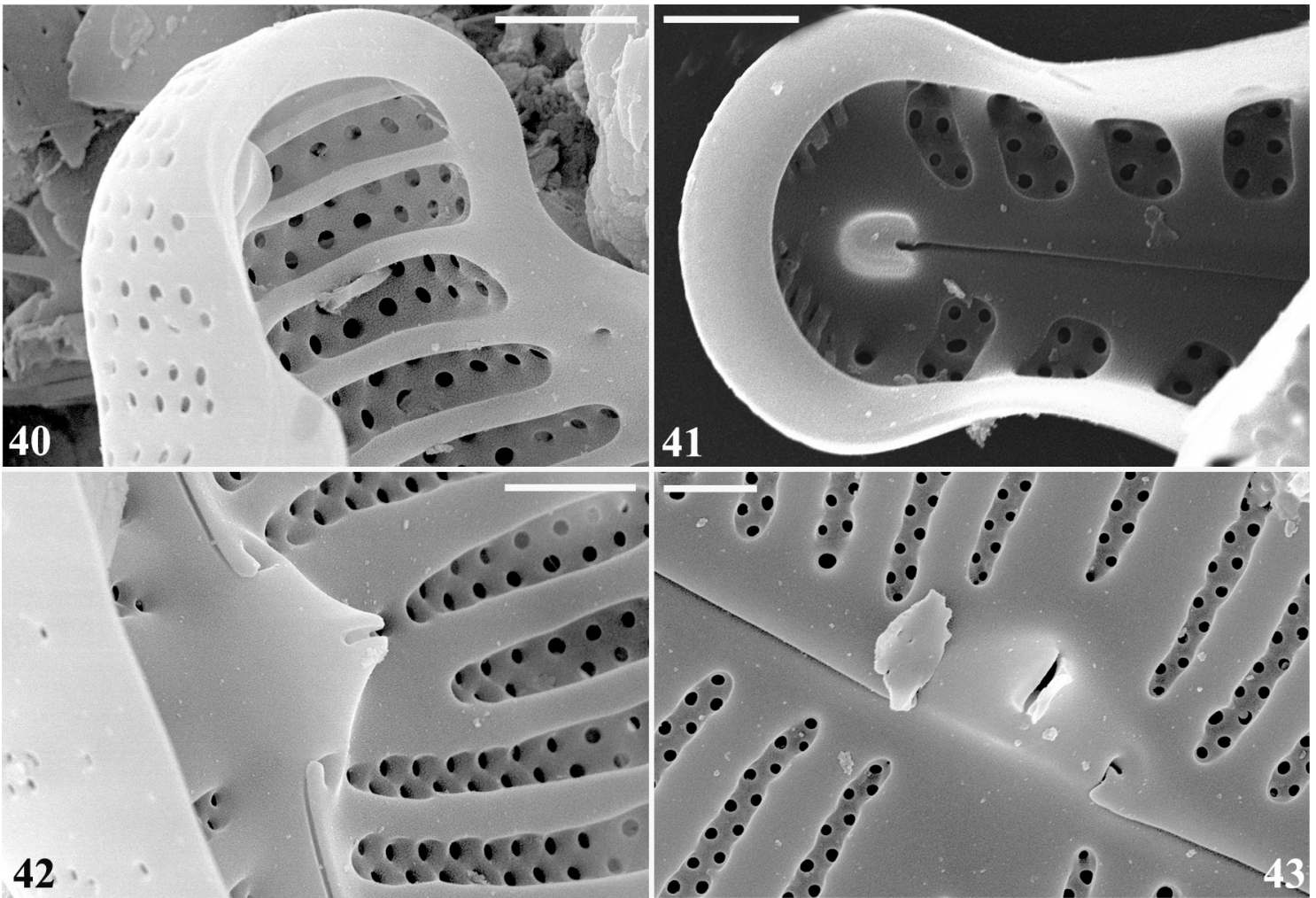

Figs 40-43. Gomphonema yunnaniana, Y. Liu et Kociolek, sp. nov. SEM, internal valve views: (40) headpole, with thin interstriae with biseriate striae evident. A pseudoseptum is at the apex. The helictoglossa is partially visible. (41) footpole, with pseudoseptum and helictoglossa evident. $(42,43)$ central nodule, showing elevated stigma opening bordered by siliceous bars. Recurved proximal raphe ends are positioned on the central nodule. Scale bars $1 \mu \mathrm{m}$.

10.1080/0269249X.2019.1574243.

Kociolek, J.P.; Balasubramanian, K.; Blanco, S.; Coste, M.; ECTOR, L.; LiU, Y.; KuliKovSKIY, M.; LuNDHOLM, N.; Ludwig, T.; Potapova, M.; Rimet, F.; Sabbe, K.; SAla, S.; SAR, E.; TAYlor, J.; VAn De ViJver, B.; Wetzel, C.E.; Williams, D.M.; Witkowski, A.; Witkowski, J. (2019): DiatomBase. Accessed at http://www.diatombase.org

Kociolek, J.P.; Woodward, J.C. \& GraefF, C. (2016): New and endemic Gomphonema C.G. Ehrenberg (Bacillariophyceae) species from Hawaii. - Nova Hedwigia 102: 141-171.

Kociolek, J.P.; You, Q.; Wang, X. \& LiU, Q. (2015a): Consideration of some interesting freshwater gomphonemoid diatoms from North America and China, and the description of Gomphosinica, gen. nov. Nova Hedwigia, Beihefte 144: 175-198.

Kociolek, J.P.; Glushchenko, A. \& KulikovskiY, M. (2015b): Typification, valve ultrastructure and systematic position of Gomphonema gomphopleuroides Amosse ex Kociolek, Glushchenko \& Kulikovskiy, an endemic diatom from Southeast Asia. - Diatom Research 30: 247-255.

Kociolek, J.P.; You, Q.; StePaneK, J.; Lowe, R.L. \& WANG, Q. (2016): A new freshwater diatom genus, Edtheriotia gen. nov. of the Stephanodiscaceae Glezer \& Makarova (Bacillariophyta) from southcentral China. - Phycological Research 64: 274-280.

Kociolek, J.P. \& Kingston, J.C. (1999): Taxonomy, ultrastructure and distribution of gomphonemoid diatoms (Bacillariophyceae: Gomphonemataceae) from rivers of the United States. - Canadian Journal of Botany 77: 686-705.

Kociolek, J.P. \& Stoermer, E.F. (1987): Ultrastructure of Cymbella sinuata (Bacillariophyceae) and its allies, and their transfer to Reimeria, gen. nov. - Systematic Botany 12: 451-459.

Kociolek, J.P. \& Stoermer, E.F. (1990): Diatoms of the Miocene Hot Springs Limestone, Snake River Plain, Idaho (U.S.A.). - Micropaleontology 36: 331-352.

Krammer, K. (1997): Die cymbelloiden Diatomeen - Eine Monographie der weltweit bekannten Taxa. Teil 1. Allgemeines und Encyonema Part. - Bibliotheca Diatomologica 36: 1-382.

Krammer, K. (1999): Validierung von Cymbopleura nov. gen. - Iconographia Diatomologica, Annotated Diatom Micrographs 6: 1-292.

Krammer, K. (2003): Cymbopleura, Delicata, Navicymbula, Gomphocymbellopsis, Afrocymbella. - Diatoms of Europe 4: 1-529.

Kulikovskiy, M. \& Kociolek, J.P. (2015): The diatom genus Gomphonema Ehrenberg in Lake Baikal. I. Morphology and taxonomic history of two endemic species. - Nova Hedwigia, Beihefte 144: 507-518.

LANGe-Bertalot, H. (2001): Navicula sensu stricto, 10 Genera Separated from Navicula sensu stricto, Frustulia. - Diatoms of Europe 2: 1-526.

LowE, R.L. (1975): Comparative ultrastructure of the valves of some Cyclotella species (Bacillariophyceae). Journal of Phycology 11: 415-424.

LI, Y.L.; Gong, Z.J.; WANG, C. \& Shen, J. (2010a): New species and new records of diatoms from Lake Fuxian, 
China. - Journal of Systematics and Evolution 48: 65-78.

Li, Y.L.; Metzeltin, D. \& Gong, Z.J. (2010b): Two new species of Sellaphora (Bacillariophyta) from a deep oligotrophic plateau lake, Lake Fuxian in subtropical China. - Chinese Journal of Oceanology and Limnology 28: 1160-1165.

Liu, Y.; Chen, G.; Shi, H.; Chen, X.; Lu, H.; Duan, L.; ZhANG, H. \& ZhANG, W. (2016): Responses of a diatom community to human activities and climate changes in Xingyun Lake. - Acta Ecologica Sinica 36: 3063-3073.

Metzeltin, D. \& Lange-Bertalot, H. (2007): Tropical Diatoms of South America II. Special remarks on biogeography disjunction. - Iconographia Diatomologica 18: 1-877.

Metzeltin, D.; Lange-Bertalot, H. \& Nergui, S. (2009): Diatoms in Mongolia. -Iconographia Diatomologica 20: 3-686.

Levkov, Z.; Mitic-Kopanja, D. \& Reichardt, E. (2016): The diatom genus Gomphonema from the Republic of Macedonia. - Diatoms of Europe 8: 1-552.

Pantocsek, J. (1889): Beiträge zur Kenntnis der Fossilen Bacillarien Ungarns. Teil II. Brackwasser Bacillarien. Anhang: Analyse de marine Depots von Bory, Bremia, Nagy-Kurtos in Ungarn; Ananio und Kusnetzk in Russland. - 123 pp., Nagy-Tapolcsány, Buchdrucherei von Julius Platzko.

PAtrick, R.M. \& ReImer, C.W. (1975): Diatoms of the United States. Volume 2, Part. 1. - Academy of Natural Sciences of Philadelphia. Philadelphia 13: 1-213.

ReichardT, E. (1997): Taxonomische Revision des Artenkomplexes um Gomphonema pumilum (Bacillariophyceae). - Nova Hedwigia 65: 99-130.

ReICHARDT, E. (1999): Zur Revision de Gattung Gomphonema. Die Arten um G. affine/insigne, G. angustatum/micropus, G. acuminatum sowie gomphonemoide Diatomeen aus dem Oberoligozän in Bohmen. - Iconographia Diatomologica 8: 1-203.

REICHARDT, E. (2007): Neue und wenig bekannte Gomphonema-Arten (Bacillariophyceae) mit Areolen in Doppelreihen. - Nova Hedwigia 85: 103-137.

REICHARDT, E. (2008): Gomphonema intermedium Hustedt sowie drei neue, ähnliche Arten. - Diatom Research 23: $105-115$.

REICHARDT, E. (2009): Silikatauswüchse an den ineren Stimgenöffnungen bei Gomphonema-Arten. Diatom Research 24: 159-173.

Reichardt, E. \& LANGE-Bertalot, H. (1991): Taxonomische Revision des Artenkomplexes um Gomphonema angustum-G. dichotomum-G. intricatum-G. vibrio und ahnliche Taxa (Bacillariophyceae). - Nova Hedwigia 53: 519-544.

Schmidt, M. (1899): Atlas der Diatomaceen-Kunde. Plate 216. - R. Reisland, Leipzig.

SHI, Z. (2004): Gomphonemaceae. - Flora Algarum Sinicarum Aquae Dulcis. Tomus XII. Bacillariphyta. -147 pp., Science Press, Beijing.

Skuja, H. (1937): Algae. Symbolae Sinicae. - Botanische Ergebnisse der Expedition der Akademie der Wissenschaften in Wein nach Sudwest-China, 1914 1918, 1: 1-105.

TAYlor, J.C.; Karthick, B.; KocioleK, J.P.; Wetzel, C.E. \& CocQuYt, C. (2014): Actinellopsis murpheyi gen. et spec. nov.: A new small celled freshwater diatom (Bacillariophyta, Eunotiales) from Zambia. Phytotaxa 178: 128-137.

Theriot, E.; Hakansson, H.; Kociolek, J.P.; Round, F.E. \& Stoermer, E.F. (1987): Validation of the centric diatom genus name Cyclostephanos. - British Phycological Journal 22: 345-347.

Wallace, J.H. \& Patrick, R.M. (1950): A consideration of Gomphonema parvulum Kutz. - Butler University Botanical Studies 9: 227-234.

Wetzel, C.E.; Lange-Bertalot, H.; Morales, E.A.; Bicudo, D.C.; HoffmanN, L. \& Ector, L. (2012): Bicudoa amazonica gen. nov. et sp. nov. (Bacillariophyta) - a new freshwater diatom from the Amazon basin with a complete raphe loss in the eunotioid lineage. - Phytotaxa 75: 1-18.

Wetzel, C. \& Kociolek, J.P. (2018): Burliganiella gen. nov. (Bacillariophyta, Eunotiales) another case of raphe reduction based on the type material of Fragilaria siolii Hustedt. - Cryptogamie, Algologie 39: 1-11.

YAnG, J.R.; Stoermer, E.F. \& Kociolek, J.P. (1994): Aulacoseira dianchiensis sp. nov., a new fossil diatom from China. - Diatom Research 9: 225-231.

You, Q.; KocIOLEK, J.P. \& Wang, Q. (2015): Taxonomic studies of the diatom genus Halamphora (Bacillariophyceae) from the mountainous regions of southwest of China, including the description of two new species. - Phytotaxa 205: 75-89.

(C) Czech Phycological Society (2020)

Received April 15, 2019

Accepted October 14, 2019 